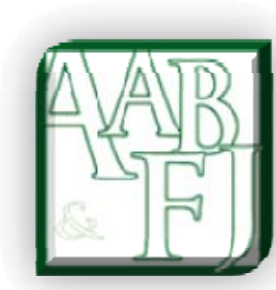

\title{
Public Sector Financial Management Reform: A Case Study of Local Government Agencies in Indonesia
}

Monir Mir ${ }^{1}$

Wahyu Sutiyono²

\begin{abstract}
:
Indonesia has taken initiatives to reform its public sector financial management. One of the reform agendas was to introduce 'cash to accrual' accounting for improved financial reporting. It is expected that improved financial reporting will enhance financial accountabilities of the governmental agencies and will assist both internal and external decision makers whose decisions will be based on the financial reports. However, it has been observed that there is a significant increase in the number of qualified audit reports when these financial reports were audited. This also means that these financial reports are lacking in providing true and fair views on the financial activities of the governmental agencies, thereby not assisting in discharging their accountabilities. This study seeks to answer the question as to why the numbers of qualified audit reports have increased despite the existence of various governmental accounting reform agendas. Based on the in-depth case studies of three Indonesian local governments, it is found that the demand, the supply and the quality assurance of the accounting information outputs in these local governments are not in parity, and this lacking in parties actually has impacted in producing unqualified and usable accounting reports.
\end{abstract}

Keywords: Public sector reform; New public management; Financial management; Local government; Indonesia.

JEL Code: M40

\footnotetext{
${ }^{1}$ University of Canberra

monir.mir@canberra.edu.au

${ }^{2}$ University of Canberra

wahyu.sutiyono@canberra.edu.au
} 


\section{Introduction and Background}

The role of accounting information in achieving organisational goals and objectives is well established. The role of accounting actually evolved and became more crucial as the complexities of organisational ownerships and characteristics evolved over the centuries. The developed countries in the world were the forerunners in making the accounting useful through bringing in increased sophistications in their accounting practices. Although late, many developing countries have also realised the roles of their accounting infrastructures in their economic developments and are following the paths of the developed countries in improving their accounting practices. The developing countries have undertaken various paths in developing their accounting infrastructure. For example, many developing countries directly adopted the IFRS in their countries (see for example, Mir \& Rahaman 2005; Chamisa 2000; Hassan 1998; Al-Rai \& Dahmash 1998; Mirghani 1998; Larson 1993; Enthoven 1973). On the other hand many developing countries modified the IFRSs as per their own business and economic cultures before adopting the IFRSs (Wallace 1990). The results of these studies are mixed. Some studies reported that the adoption of IFRSs (previously IASs) by developing countries without modification was a success (e.g. Chamisa 2000). Other studies reported that the direct adoption of the IASs by developing countries was not successful with respect to the perceived outcome from the adoption of IFRS - for example: Mir and Rahaman (2005) on Bangladesh, Chand (2005) on Fiji, Dahawy and Conover (2007) on Egypt, and Kholeif (2010) on Egypt.

However, the evolution of the accounting practices globally, especially within the free market economies, was centred on private sector businesses and organisations. It is during the late eighties and early nineties when some of the developed countries (e.g., Australia, New Zealand, Sweden, and the UK) directed their attentions towards reforming the public sector accounting through the various public sector financial management reform initiatives (Grossi \& Newberry 2009; Lucio et al. 1997; Parker \& Guthrie 1993; McCulloch 1993).

The main motives for such reforms, some studies have noted, include the need for efficiency, effectiveness and economy, and have centred on operational and financial management processes of public sector entities (Tomkins 1987; Broadbent \& Guthrie 1992; Pallot 1992; Guthrie 1993; Parker \& Guthrie 1993; Guthrie \& Humphrey 1996). While some prior studies have shown an absence of management resistance and significant improvements to the financial management processes of particular public sector agencies (e.g. Jacobs 1997, 1998; Mir \& Rahaman 2003a 2003b, 2006, 2007), the vast majority has clearly noted significant financial management difficulties provoked by public sector reforms (e.g. Pallot 1992; Puxty 1997; Lawrence 1999; Lowe 2000; Manning, 2001; Newberry and Pallot, 2004; Meier and O’Toole, Jr., 2009; Llewellyn \& Northcott 2005; Bezes et. al., 2012; Cutler, 2012; Lee, 2012). One of the key elements in the financial management reform process is the utilisation of accounting techniques hitherto operative in conventional profit-orientated entities for planning and decision making in the new public sector environment. Such practice has been labelled 'the new public management regime,' and has become the subject of numerous prior studies in the accounting literature (Hood 1995; Lapsley 1999).

All these studies reported the 'new public management' type accounting and financial reform processes of the developed countries. The reason for this is that like the sophisticated developments of the private sector accounting infrastructure, the developed countries also have become the forerunner of the reform processes of their public sector accounting infrastructure. Although many developing countries followed the developed countries in developing their private sector accounting infrastructure, the momentum is yet to come with respect to following the 'new public management' type accounting and financial management reforms in their public sectors. One exception in this respect is Indonesia, which introduced 'new public management' type accounting and financial management reforms in its public 
sector accounting domain some time ago. One of the financial management reforms that Indonesia has introduced is the implementation of 'cash towards accrual' accrual accounting in the financial reporting systems of the governmental agencies to enhance the discharging of their accountabilities.

Although there are studies which have reported the experience of the various public sector reform processes in the developed countries, a study is yet to report empirically the experience of a developing country in this regard. This paper contributes to the literature in this area by exploring the public sector financial management reform experience of Indonesia. We investigate how the democratic political transformation process of Indonesia demanded greater transparency and accountability from the public sector and how this demand eventually prompted demands for commercial accounting and public sector accounting standards in Indonesia. We attempt to understand the outcome of the Indonesian public sector accounting reforms through the concept of accounting infrastructure development (Wallace \& Briston 1993). The main objective of the paper is to explore whether these elements of accounting infrastructure are able to synchronise and influence the expected outcome of the public sector accounting reforms in Indonesia, that is, the discharging of accountabilities of the governmental agencies. Three in-depth case studies involving three local governments were conducted to achieve the research objective.

The rest of the paper is organised as follows: we start with a discussion of the concept of accounting infrastructure development that informs our analysis and interpretation of empirical data. This is followed by the discussion of the public sector accounting reforms in Indonesia. We then focus on the outcome of the Indonesian public sector accounting reform process, drawing on the concept of accounting infrastructure development before providing summary insights and conclusions.

\section{Theoretical Framing: The Concept of Accounting Infrastructure}

According to Wallace and Briston (1993 p. 202) the accounting infrastructure of a country comprises three facilities which consist of (i) the facilities of information production that is the supply function, (ii) the framework of information diffusion that is the demand of the accounting information, and (iii) the foundation of information monitoring and contract information that is the quality and the regulatory mechanism that exist in country with respect to its accounting infrastructure. Actually, Wallace and Briston's accounting infrastructure argument follows the concept of accounting infrastructure proposed by Lee (1987 p. 79). Lee points out four basic elements which make up the accounting information structure: 1) the information producer and final user; 2) the information intermediaries; 3) the laws and regulations that govern the production, transmission, and usage of information; and 4) the legal entity that monitors and implements the laws and regulations. Lee (1987) emphasises that proper functioning of these elements contributes in achieving the roles of accounting with respect to information production and diffusion as well as these elements providing the foundation of information monitoring and contract information. With respect to the status of accounting infrastructure in developing countries, Lee (1987) also notes that in developing economies most human resources and capital goods are allocated to agriculture and manufacturing sectors and that investment in the accounting information infrastructure is minimal.

The supply of accounting information is dependent on the training and education of accountants and auditors, and the availability of quality institutions and equipment in sufficient number to assist the accounting information producers. The demand of accounting information mainly comes from the information users, including information intermediaries, 
information screening mechanisms such as inter-firm comparison, stock exchanges and banks. The quality of accounting information is dependent on the related laws and regulations of a country that govern the production, transmission and usage of accounting information. These basic elements influencing the types of accounting that exist in a country are depicted in Appendix 1. As can be seen from the figure in the Appendix, these basic elements of accounting are also influenced by a country's political, economic, social, educational and cultural factors. For example, Wallace and Briston argue that an increase in the level of education in a country may increase political awareness and demand for accountability. Again, cultural variables may also affect accounting. For example, in societies where a strong oral tradition exists or where corruption is endemic, the development of accounting may be impeded even if the demand, supply and regulations elements of the accounting infrastructure of a country are in a balanced state.

In the context of governmental accounting innovation, Luder (1992) argues that innovation in governmental accounting is influenced by the existence of markets for users and producers of governmental accounting information. Luder through his 'contingency model' also points out that the attitude and behaviour of users and producers of accounting information is shaped by their respective environments. Luder further emphasises that some kinds of stimuli (such as public sector reform initiatives) and the interaction between demand and supply could spark governmental accounting innovations.

The models of Wallace and Briston and Luder points out a couple of significant variables to that needed to be taken care of in implementing accounting systems. That is, they suggest that the demand for and supply of accounting information is crucial to implement any changes or innovation in the accounting system of an economy. While the model of Wallace and Briston did not attract much attention by the academia, Luder's contingency model has been widely used in comparative international governmental accounting research (see for example Harun \& Robinson 2010; Saleh 2007; Lee 2001). Nevertheless the current study adopted Wallace and Briston's framework as its theoretical lens because the model has added another important dimension. As indicated above, Wallace and Briston suggest that in order to get successful outcomes of any governmental accounting changes the demand, supply and regulation of the information should be in a balanced state. Therefore, the framework is particularly useful for developing theories and testing hypotheses about the functioning of accounting across the world and relationships between accounting and its environment.

Wallace and Briston argue that many accounting development projects and approaches in upgrading infrastructure in developing countries have emphasized the improvement of the supply side of the equation rather than the strengthening of the factors that could increase the demand and improve the quality of accounting information. The three elements of supply, demand and quality control of accounting information should be in an optimum balanced state and should also make progress side by side within the accounting infrastructure building process of a country. For example, if a country invests in improving the supply side of its accounting infrastructure without considering the demand and quality of the accounting information and vice versa, the improvement of accounting infrastructure in that country would be slow. It is like somebody buying a sophisticated HD video camera because everybody around already has one, but he or she has no use for the video camera. Any country should look at these accounting infrastructure elements before the leap for their accounting infrastructure developments.

\section{The Indonesian Public Sector Accounting Infrastructure}

Wallace and Briston (1993) argue that the basic elements of accounting infrastructure (i.e., the demand, supply and regulation of accounting information) are influenced by a country's political, economic, social, educational and cultural factors (see Appendix 1), and that the 
national accounting infrastructure programme suitable for a country would depend on the circumstances of the country. In the context of Indonesia, Kristiansen et al. (2008) report that national systems and traditions of politics and bureaucracy have a strong negative impact on local administrative procedures, leaving only marginal space for regional variance and improvements. They further argue that there is a remarkable lack of transparency and checks and balances in public financial affairs in Indonesia.

Indonesia's socio-political circumstances have changed tremendously since the late nineties. Indonesia's political, economic and social institutions have experienced significant change and political reform, and decentralisation has been accompanied by moves to adopt more sophisticated accounting approaches in the public sector since the collapse of the Soeharto regime in 1998 (Harun 2007). These reforms relating to public sector financial management flow from a recognition that the proper functioning of democracy at both central and local levels required detailed evaluation of the efficiency, effectiveness and integrity of government's use of scarce resources in discharging their accountabilities. The socio-political reforms in Indonesia have influenced Indonesian politicians and policy makers to reform, among other things, its public sector accounting infrastructure. This section discusses Indonesia's public sector accounting reforms, drawing on the accounting infrastructure elements framework of Wallace and Briston (p. 202), namely, the demand factor, supply factor and regulatory factor.

The Demand Factor

It is expected that the demand for the Indonesian governmental financial statements would mainly come from the following stakeholders:

- citizens;

- National Parliament (Dewan Perwakilan Rakyat, DPR), supervisory agency and audit agency;

- other stakeholders which are involved in donations, investments and loans, and

- the government itself

The demand for the Indonesian governmental financial statements is also influenced by the demand to create good governance. Therefore, the government financial statements are also expected to fulfil the following demands:

- accountability: as an accountability tool of management to manage and implement particular resources in order to achieve the designated objectives;

- management: decision-making related to planning, managing and controlling the assets, liabilities, and the equities of the government funds;

- transparency: to prepare a transparent, honest and comprehensive financial report to shareholders

Marwata and Alam (2006) argue that the local governmental accounting system in Indonesia is complex. They further argue that there is rarely any demand of the accounting information from one of the important stakeholders of the local governmental accounting reports, that is, the citizens of the local governments. As a result local governments have no motivation to use accounting information to discharge their accountabilities.

\section{The Supply Factor}

It is mentioned earlier that the supply of accounting information is dependent on the training and education of the accountants and the auditors, the availability of quality institutions, and equipment in sufficient number to assist the accounting information producers. The accounting profession in Indonesia is regulated and controlled by the Indonesian Accounting Association (IAA) which was established in December 23, 1957. At the time of the writing 
the IAA has 6,899 members spread across Indonesia, which is divided into 20 regions. The IAA has four compartments with special guidelines to improve professionalism and to run professional activities and scientific function according to their field of work. These are:

1. Management Accountants Compartment;

2. Public Accountants Compartment;

3. Educational Accountants Compartment;

4. Public Sector Compartment.

The public sector compartment of the IAA (known as IAA-CPSA) deals with the training and education of public sector accountants and auditors. The objectives of the IAACPSA are: (1) to preserve the status and honour of the public sector accounting profession; (2) to improve the capability and responsibility of the public sector accountant profession; (3) to assist the public sector accountants in implementating their profession smoothly and responsibly; and (4) to improve the professional roles of the public sector accountant over time. IAA-CPSA has three categories of memberships: regular member, special member, and honorary member. In order to preserve the institution's professionalism, IAA has sanctioned mechanisms against the violations of their professional ethos in the form of (1) a written notice; (2) temporary suspension; (3) permanent dismissal. Each member of the IAA-CSPA is expected to go through ongoing professional education (SPE) involving the process of continuous learning to enhance their professional competencies.

There are a number of training institutions including universities and colleges that also produce graduate accountants and some of these go through the process of the IAA to become professional accountants. However, very few of these instititions engage their resources in producing public sector accountants. Therefore, most of the university and college graduates including the professional accountants end up taking careers in private sector accounting. There are significant differences on the application and use of accounting information between private and governmental sectors, and the accounting training and education systems of Indonesia are yet to appreciate this.

\section{The Regulatory Factors}

The demand for public sector accounting reform in Indonesia was stimulated after the collapse of the Soeharto regime in 1998 (Harun 2007), although smaller initiatives have occurred since the seventies. During the administration of this regime, public sector accountability and efficiency lacked transparency. Political reforms and democratisation in Indonesia since then has aimed at detailed evaluation of efficiency and effectiveness of the government's use of scarce resources. As a result, various public sector accounting reforms were attempted at Indonesian governmental accounting levels. The stages of public sector accounting reforms and the corresponding periods are summarised in the following paragraphs:

1979-1980:

During this time the governmental administrative system was manual and there were no standards in existence with respect to Indonesian government accounting. A Budget Realisation Report was the only accountability report that was presented to parliament. The report was prepared manually based on a single entry system. During this period the Indonesian Ministry of Finance started to develop a Study Plan to modernise the Indonesian government accounting system. 1986:

One outcome of the Study Plan mentioned above was the establishment of the Central Government Accounting System and the Institution Accounting System Design. The Ministry of Finance used these systems to set up the budget allocation, the cash inflow 
and the cash outflow of the State Office of Treasury. The system was based on the manual method of journalising and general ledger maintenance.

1987-1988:

The use of a computerised accounting system was proposed and a proposal of a computerised governmental accounting system was approved. 1992:

The State Financial Accounting Agency (BAKUN) was established and started functioning as the Central Accounting Office. The agency was assigned with the responsibility of setting up public sector accounting standards.

2003-2004:

The Indonesian public sector accounting reform initiatives started with the enactment of three Laws relating to state finance:

1. Law No. 17/2003 on State Finance;

2. Law No. $1 / 2004$ on State Treasury;

3. Law No. 15/2004 on Audit on Management and Accountability of State Finance

In addition to the enactment of three Laws a Standard Setter Body (KSAP) was established by the enactment of Presidential Decree No. 84/2004. 2005:

The Presidential Decree No. 84/2004 related to the setting up of the Standard Setter Body was amended by the Presidential Decree No. 2/2005. Government Accounting Standard (SAP) was set up in 2005 by the Government Regulation No. 24/2005. From 2005 the Central Government Financial Statement was presented based on the Government Accounting Standard.

The Indonesian Government Accounting Standard (SAP) derives from international best practices through adapting the International Public Sector Standards (IPSAS) which was published by the International Federation of Accountants (IFAC). While many developing countries adopted international accounting standards straightforward without any modification (see Mir \& Rahaman 2005), Indonesia took the 'adoption with modification' path. Although Indonesia adopted the main principles of IPSAS, the SAP also considered certain conditions in Indonesia such as its domestic laws, existing financial practices, and the readiness of its human resources. The majority of the existing literature on the adoption processes of the international-based accounting standards by developing countries reported that the implementation and compliance of modified international standards would be higher compared to the straightforward adoption the international standards (see for example, Enthoven 1973; Larson 1993; Mirghani 1998; Al-Rai \& Dahmash 1998; Hassan 1998; Chamisa 2000; Mir \& Rahaman 2005). It is therefore expected that the Indonesian experience of IPSAS adoption and implementation would be positive. The SAP consists of the following components: the conceptual framework of government accounting, eleven statements of government accounting standards, and five technical bulletins. However, there is no component containing the interpretation of standards. The development and the implementation of the SAP coincided with the transitional process from cash basis towards accrual basis of accounting and reporting (popularly known as 'Cash towards Accrual' basis). References on setting up the SAP are mainly derived from:

- International Federation of Accountants;

- International Accounting Standards Committee;

- International Monetary Fund;

- Indonesian Accounting Board;

- Financial Accounting Standard Board - USA;

- Governmental Accounting Standard Board - USA; 
- Indonesian laws on state finance;

- Other international organisations which are involved in public sector accounting and government audit

The implementation process of 'cash towards accrual' (CTA) commenced in the 2007 financial year. All these public sector reform initiatives are summarised in Appendix 2. As can be seen in Appendix 2, the main outcome that is expected from the Indonesian public sector financial management reform is the increased accountability of the public sector agencies at national and sub-national levels with respect to their uses of public money. As discussed in this section, one of the most significant public sector accounting reform initiatives in Indonesia was the adoption of public sector accounting standards (SAP) in 2005. Accounting standards contribute towards improved external accounting reporting, and the annual reports of companies, especially the annual reports of public sector entities, are the important pillars of discharging their accountabilities. Therefore, the SAP, among other public sector financial management reform initiatives, is expected to facilitate the discharging of accountabilities within the public sector agencies in Indonesia. However, as discussed in following sections, this is not the case with the outcome of the public sector financial management reform initiatives in Indonesia.

\section{Audit Outcome and the Compliance of the Sap at the Sub-national Government Level}

We commence this section through an overall discussion of the implementation outcome of the introduction of public sector accounting standards (SAP) at the Sub-national Government levels in Indonesia. The financial and accountability reports at the Indonesian sub-national government levels (SNG) is prepared and presented on the basis of SAP. The financial statement consists of four components: a regional budget realisation report, a balance sheet, a cash flow report, and notes of financial statements.

The head of each regional government submits a draft report on regional regulations on accountability based on an audited regional budget, at least six months after the end of fiscal year (Indonesian fiscal year ends December 31). The finance functions of the SNGs are regulated by the following legislations:

- Regional Financial Administration Manual (MAKUDA) 1981

- Accounting system based on the SAKD version working team on Ministry of Finance Regulation No. 355/2001

- Ministry of Home Affairs Regulation No. 29/2002

- Ministry of Home Affairs Regulation No. 13/2006 on Regional Finance Management Guidelines

- Ministry of Home Affairs Regulation No. 59/2008 on Regional Finance Management Guidelines

Table 1 and Figure 1 summarise the audit result from the Indonesian Supreme Audit Board of the SNGs' financial statements for the fiscal year of 2004-2007:

Table 1: Audit opinion

\begin{tabular}{|c|c|c|c|c|c|}
\hline $\begin{array}{c}\text { LG } \\
\text { (Entity) }\end{array}$ & \multicolumn{5}{|c|}{ Audit Opinion } \\
\hline FY & $\begin{array}{l}\text { Unqualified } \\
\text { (WTP) }\end{array}$ & $\begin{array}{l}\text { Qualified } \\
\text { (WDP) }\end{array}$ & $\begin{array}{l}\text { Disclaimer } \\
\text { (TMP) }\end{array}$ & $\begin{array}{c}\text { Adverse } \\
\text { (TW) }\end{array}$ & $\begin{array}{l}\text { Grand } \\
\text { Total }\end{array}$ \\
\hline
\end{tabular}




\begin{tabular}{|c|c|c|c|c|c|c|c|c|c|c|} 
& Entity & $\%$ & Entity & $\%$ & Entity & $\%$ & Entity & $\%$ & Entity & $\%$ \\
\hline 2004 & 21 & 7.32 & 249 & 86.76 & 7 & 2.44 & 10 & 3.48 & 287 & 100 \\
\hline 2005 & 17 & 4.70 & 308 & 85.08 & 25 & 6.91 & 12 & 3.31 & 362 & 100 \\
\hline 2006 & 3 & 0.65 & 326 & 70.41 & 106 & 22.89 & 28 & 6.05 & 463 & 100 \\
\hline 2007 & 3 & 1.09 & 173 & 62.91 & 48 & 17.45 & 51 & 18.55 & 275 & 100 \\
\hline
\end{tabular}

(Source: Supreme Audit Board, 2008 (Ikhtisar Hasil Pemeriksaan Semester I Tahun Anggaran 2008, Badan Pemeriksa Keuangan RI, Jakarta, September 2008))

The Supreme Audit Board's audit opinion on SNG financial report for period of 20042007 is clearly a disappointing picture. The percentage of reports with 'Unqualified' opinion decreased from 7\% in 2004 to 1\% in 2006 and 2007. The percentage of reports with 'Qualified' opinion decreased further each year. In comparison, the percentage of reports with 'Disclaimer' or 'Adverse' opinion increased rapidly in 2004-2007. The percentage of reports with 'Disclaimer' opinion rises rose from 2\% in 2004 to $17 \%$ in 2007.

In the same period, the percentage of reports with 'Adverse' opinion rose from $4 \%$ to $19 \%$. There were also a great number of SNGs which did not fulfill their reporting schedule to be audited by the Supreme Audit Board as stipulated in Law Number 1/2004. From 468 SNG financial reports in 2007, which should have been received by the Supreme Audit Board to audit in first semester of 2008, only 436 reports were submitted and 275 audited. 32 SNG reports were not submitted and the rest were still in audit process because of late submission to the Supreme Audit Board.

The audit opinions are mainly based on four areas:

- compliance with SAP (including compliance with the CTA in the year 2007)

- adequate disclosures

- compliance with existing laws

- effectiveness of the internal control system

Figure 1: Audit opinion type in percent

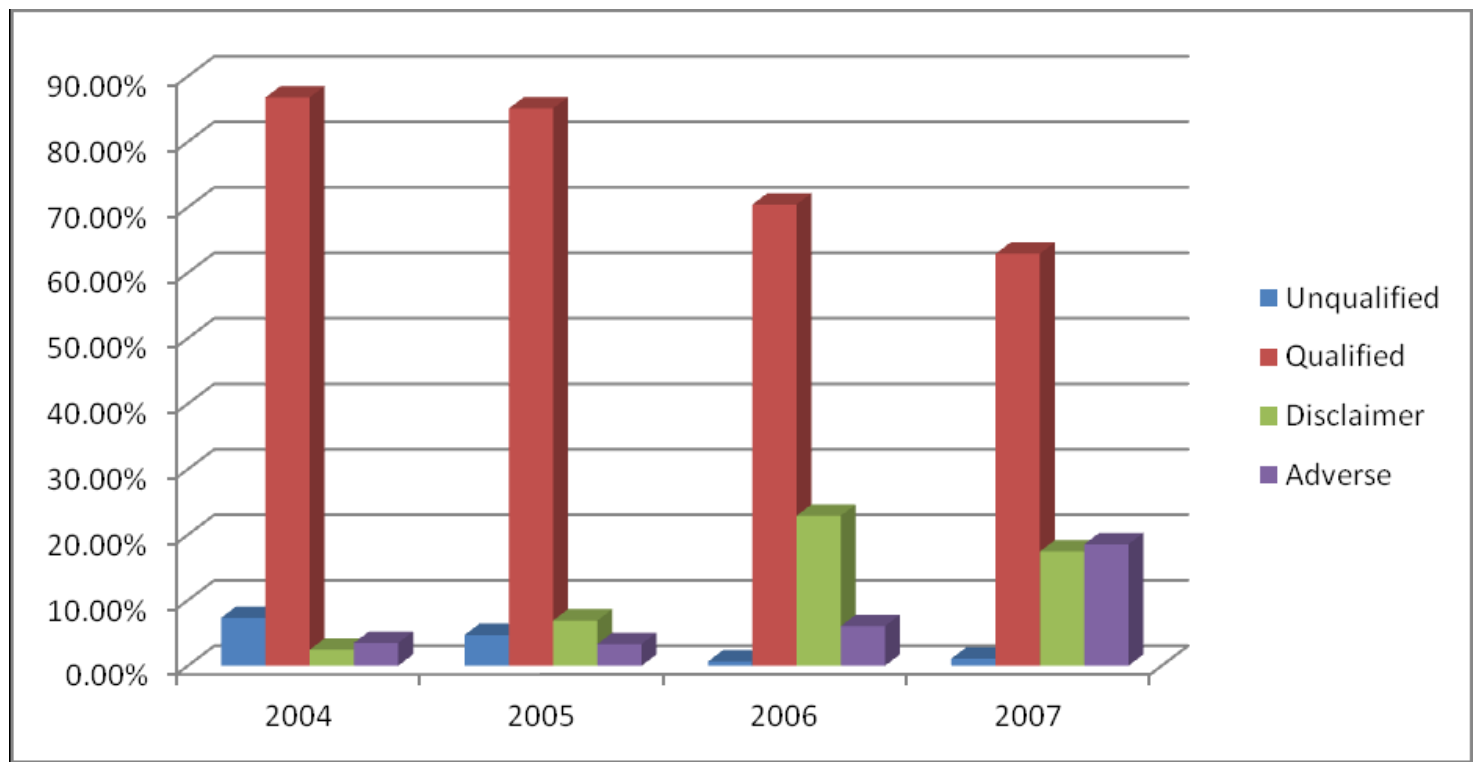


(Source: Supreme Audit Board, 2008 (Ikhtisar Hasil Pemeriksaan Semester I Tahun Anggaran 2008, Badan Pemeriksa Keuangan RI, Jakarta, September 2008))

As can be seen from Table 1, the audit opinion was stated as "Qualified" for 1,056 entities out of a total of 1,387 entities for the period 2004-2007. According to the accounting infrastructure development framework of Wallace and Briston (1993), annual reporting contributes towards the supply and regulation elements of the accounting infrastructure. Annual reports are also the pillars of discharging accountability. The information provided in annual reports reflect the aggregate impacts of multiple performance areas, including the status of discharging accountabilities by an organisation (Merchant \& Van der Stede 2012). Therefore, the existence of a large number of "Qualified" audit opinions on the annual reports of the various Indonesian governmental agencies suggests that the public sector reform initiatives - such as the introduction and adoption of the public sector accounting standards including the adoption of CTA-have failed to deliver the intended results of improved transparency, accountability and efficiency in Indonesia. It is highly likely that there is a synchronisation problem in the demands for public sector accounting information, the supply of the public sector accounting information and the quality control mechanisms in the public sector accounting information infrastructure of Indonesia. As will be discussed later in the case study section, the problem is due to the fact that the public accounting infrastructure in Indonesia is facing problems in all of the three basic elements of the accounting infrastructure.

\section{Research Method}

This study is exploratory in nature. For this purpose, qualitative approach is utilised using a multiple case study method which is instrumental in understanding complex organisational phenomena (Yin 2003). The multiple-case approach could yield more compelling evidence than the use of a single case (Yin 2003) as it allows replication of findings across cases and enables distinction between cases on dimensions that are conceptually meaningful (Miles \& Huberman 1994).

Thus, three cases of the sub-national governments of Jakarta, Tangerang and Pandeglang were selected, each with different characteristics, and receiving different levels of audit outcomes. Jakarta is the capital of Indonesia and is located in the special territory (Daerah Khusus Ibukota, DKI). Tangerang is a municipality and a satellite city of Jakarta. The municipality received an award in 2007 for preparing the best financial report ("Unqualified") at the sub-national governmental level. Pandeglang is a district in Banten. While Tangerang received an award for best financial reporting, several of the executive members of the Pandeglang council were previously arrested on corruption charges. Therefore the three SNGs differ significantly with respect to their financial reporting performances as well as with respect to their resource capabilities. These differences among the SNGs are expected to give rich insight with respect to the research question of the paper.

The annual reports for the years 2004 to 2007 of the three SNGs were collected to examine the contents and explore the views that were raised by the National Audit Office. Following the content analysis of these annual reports, follow-up interviews were conducted with the SNG where further clarification was required. These clarifications were again principally centred on the qualified opinion issues. Table 2 provides the audit outcomes of the financial reports of the three SNGs. 
Table 2: Audit outcome of the three SNGs

\begin{tabular}{|c|c|c|c|}
\hline Year & Jakarta & Tangerang & Pandeglang \\
\hline $2004-2006$ & $\begin{array}{c}\text { Qualified } \\
\text { (WDP) }\end{array}$ & $\begin{array}{c}\text { Qualified } \\
\text { (WDP) }\end{array}$ & $\begin{array}{c}\text { Qualified } \\
\text { (WDP) }\end{array}$ \\
\hline 2007 & Disclaimer & $\begin{array}{c}\text { Unqualified } \\
\text { (WTP) }\end{array}$ & $\begin{array}{c}\text { Qualified } \\
\text { (WDP) }\end{array}$ \\
\hline
\end{tabular}

The main sources of data were interviews and archives. Data were mainly collected through focus group interviews for a period of five weeks in early 2009 and again in early 2010. Permission was granted for all interviews to be recorded and later transcribed but respondent anonymity was guaranteed. A broad spectrum of respondents was selected for the interviews, including those involved directly in making decisions concerning the implementation of the public sector accounting standards. A list of the interviewees is provided in Appendix 3. All interview questions were open-ended and unstructured to allow respondents to provide their views through a 'free-flowing' discussion. Among the most critical issues discussed with respondents was the poor audit outcome of the financial reporting of the SNGs. Respondents were particularly asked to identify perceived critical problems as to why SNGs were continuously getting "Qualified” type audit reports. The length of most focus group interviews ranged between one to two hours. In addition, notes were taken of major issues raised by respondents not only for back-up purposes but also as a reference during subsequent interviews. Thus each of the cases is scrutinised in terms of its supply, demand and quality factors.

\section{Research Findings Theoretical Reflections}

\section{Supply factor}

The supply of accounting information is dependent on the training and education of accountants and auditors, the availability of quality institutions and equipment in sufficient number to assist the accounting information producers.

Formal education:

When the Indonesian public sector accounting reform was introduced in 2003, the SNGs found themselves lacking people with accounting skills. As a respondent pointed out:

We used to not have anybody with accounting skills. It was only recently that we recruited graduated of accounting. Yes, it was since the introduction of law that we really think seriously of people with proper accounting skills. (Interviewee \# J-1)

Officials in sub-nationals that possess accounting skills are graduates who had undertaken accounting in their tertiary education, either at university or in vocational education (Diploma level). Some are graduates from public administration colleges run by the government, such as the College of Sate Administration (Sekolah Tinggi Administrasi Negara, STAN).

\section{Short training:}

The interviews also revealed, however, that there are many employees with no accounting background that obtained accounting skills through self-learning and training in their employment. In this respect two respondents commented that, 
We did not have enough knowledge and skills to prepare the financial report. It was practically learning by doing. (Interviewee \# T-2)

Lack of skills is a big challenge for us. Training programmes such as those held by our local government training programs and Ministry of Finance are expected to be useful in filling the skill gap but in reality this is not happening as often training is provided on the issues irrelevant to our actual skills requirements. (Interviewee \# P-1)

In this regard, various agencies run short training programmes that provide 'technical guidance' hence are called so (Bimbingan Tehnik, Bintek), specifically conducted by the State Financial Accounting Agency (BAKUN) under the auspices of the Ministry of Finance, the Ministry of Home Affairs and the State Development Finance Comptroller (BPKP). Whilst covering basic accounting skills, the programs are a means for the government to systematize accounting standards. The variety of providers, however, often resulted in conflicting messages to the SNGs and different approaches to accounting subject matter. According a respondent (Interviewee \# J3):

These training providers are even not in agreement with respect to the merits and demerits of either the cash basis accounting or accrual basis accounting or even the benefits of the CTA. During the training process, same Trainer criticises all bases of accounting...we become more confused as to why we are attending the training...

Technical assistance:

This study found that all of the SNGs under study used consultants to prepare their financial reports. Despite the training provided, all SNGs in the study found themselves not proficient in preparing financial reports. Managers interviewed stated that because of the pressures of change, lack of skills, and law and regulations that were inconsistent and changed rapidly, they needed assistance in preparing their financial reports. Managers interviewed expressed that there appears to be a constant need by SNGs for assistance. As one respondent commented:

From year to year we rely on consultants to help us prepare the financial report. We just don't have the people and capacity that can meet the level that is expected to produce good quality of reports. (Interviewee \# J-2)

As a result, consultants both from within and outside government were invited to assist. The Jakarta municipality, for example, has used consultants to prepare their financial reports since the reform. With the huge challenge of managing the country's capital city, the demand for accountability and transparency has presented Jakarta with enormous problems in preparing financial reports. Tangerang, the recipient of the award, also used an external consultant. This demonstrates that their expertise is borrowed and may not be sustainable in the long run if accounting skills are not built in the organisation.

Professional bodies:

There are no public servants of the SNGs in the study who are members of accounting professional bodies. Even the SNG located in Jakarta, in which the Indonesian Accounting Association is headquartered and most active, has no officials dealing with accounting reports who are members. Given the dynamic of accounting professional bodies in Indonesia, SNGs seems to have missed the opportunities of keeping up with development in the profession. This shows the lack of exposures to new developments in the profession.

Information systems: The use of information systems for financial reporting preparation in the SNGs is still in the early stages. All SNGs in the study felt that it is very important that 
they use one and that they be connected online with their business units. As a respondent commented:

It would be great if we could use a mainframe or a database. We could work more efficiently.... (Interviewee \# J-2)

Interviewees noted that this can increase efficiency and cut bureaucratic processes.

\section{Demand factor}

The demand for accounting information mainly comes from the information users, including other government agencies, business organisations, non-government organisations, and the general public. All SNGs in the study noted that the demand for accounting information has increased substantially in the recent past. This demand arose from various efforts in reforming the public sector and because of the decentralisation of power from central to subnational government since 2001. SNGs report their financial information to various bodies, both within and outside the government. However, it is found that demands for the accounting information by these various stakeholders are in fact actually pseudo demand as they rarely use the information or diffuse the information (see Wallace \& Briston 1993, p. 202) for their decision making.

\section{Government agencies:}

Within the government, financial information is reported to the Ministry of Finance for accountability purposes for funds allocated by it to the SNGs. For auditing purposes, SNGs also report to the Supreme Audit Board (Badan Pemeriksa Keuangan, BPK). The Ministry of Home Affairs (MOHA) is also the recipient of the SNGs' financial reports, following regulation issued by the ministry (no. 59, 2008). For the latter, however, there was a feeling that this may not be necessary and also lacked legal basis. The involvement of local parliament (DPRD) in overseeing financial reports at the local government level was felt stronger in the decentralisation era. However, there was some doubt amongst the SNGs on the ability of members of the local parliament to understand financial reports and, as a consequent, of their capacity to provide useful feedback for them. They receive reports from the SNGs but rarely use these in decision making. Pressure from the capital market regulator (BAPEPAM) was felt by the Jakarta municipality when its proposal to issue bonds was rejected. This was due to the fact that a SNG must meet requirement of having "Unqualified status for its financial reports for three consecutive years prior to submission.

Non-government organisations:

With the increasing democratisation in Indonesia, all SNGs in the study have experienced the demand for greater transparency, particularly demanded by non-government organisations (NGOs). For example, NGOs that are concerned with the environment scrutinise financial information that relates to environment. As part of corruption eradication initiatives in Indonesia, NGOs in one of the SNGs would look for signs for this in the salary of government officials. However, the "Unqualified" status of financial reporting seems to have increased trust from NGOs. As a respondent commented,

NGOs used to scrutinise our salaries, especially incentives, for signs of corruption. But since our financial report received Unqualified status, they left us alone. (Interviewee \# T-3)

The general public:

Announcement of financial reports in the media was a new practice done by SNGs and this is regarded as a big step to address transparency. The upside of this action was felt by 
Tangerang as it claims that publication has increased the pseudo trust level and has quietened somewhat enquiries and scrutiny from the public. As one respondent commented,

In the past, various parts of the general public were chasing us for all sorts of information about our financial matters. But since we published our financial reports in the media, the enquiries were not as many as they used to be. (Interviewee \# T-1)

Empirical evidence provided in this section clearly indicates that demands for the use of financial reporting information are in fact pseudo demands. Indonesian public servants do not use financial reporting information significantly for their day to day decision making.

Quality

Production of law and regulation:

Law and regulation for accounting reports by SNGs is set by the Ministry of Finance (MoF) and the Ministry of Home Affairs (MoHA). Information from the interviews denotes that there are conflicting laws and regulations that govern the production of financial information and reporting. Firstly, new laws and regulations from a ministry often conflict with those issued earlier by the same ministry. This has resulted in SNGs needing to adjust or even convert the already drafted financial report. This had caused confusion and inefficiency on the part of the SNGs. As one respondent commented:

We have been trying to cope with the changing of the laws but things have not been easy. To start with, our people did not have the necessary skills to carry out the new way of reporting as stipulated the law. Before we mastered the new system, a new law was issued. (Interviewee \# J-1)

Another respondent had the view that,

The new law was not only different but in many ways conflicting with the old one and we were at a loss. Our report that we thought still needed improvement had to be converted to meet the requirement of the new law. (Interviewee \# P-5)

Secondly, different central agencies often required different kinds of accounting reports. SNGs are of the opinion that they are torn between MoF and MoHA. In fact, SNGs must rewrite their reports to suit each agency's requirements. Managers interviewed considered this as unnecessary and caused inefficiency. So, these SNGs in fact prepare two sets of financial reports based on cash basis and CTA basis which strains their financial and human resources.

Thirdly, introduction of law and regulation has caused problems. Many interviewees felt that new laws and regulations were issued without detailed guidance and it could take a year or two until proper direction was received. Local government therefore must grapple with interpreting the new laws and regulations. Interviewees are of the opinion that regulations are not consistent and that they change too quickly resulting in inefficiency and non-optimal preparation of financial reports.

Transmission of law and regulation:

Interviews in the SNGs noted that decentralisation required them to communicate financial reports with the stakeholders, such as the public and local parliament. SNGs in the study appeared to have used various communication media, a practice that was not done before.

In Jakarta, the municipality provides soft copies on CDs to those requesting financial information. The municipality felt that the era of democratisation and increasing transparency had forced them to be more transparent to stakeholders such as the Commission of Corruption Eradication (Komisi Pemberantasan Korupsi, KPK). NGOs in the field of with 
environmental concerns were able to look at the local government's spending relevant to their needs. In Pandeglang, the financial report is published in the local newspaper.

Although SNGs are increasingly publishing their annual reports, publication has not contributed in improving the quality of their accounting information. Respondent J-3 mentioned that they publish annual reports in the newspaper and on websites as a ritual and to improve their SNG's image on the basis that the SNG is trying to be transparent. In fact, they publish reports which have already received 'Adverse' or 'Disclaimer' opinions from the auditor. The same respondent mentioned that even in some cases the published information quickly becomes redundant due to changes in the public sector financial management regulations. Therefore, publications of annual reports in newspapers and on websites have not impacted the quality of the accounting information.

All three SNGs that were investigated face problems with respect to regulation and quality aspects, the supply aspect, and the demand aspect of the accounting infrastructure. It has been observed that the SNGs have to cope with frequent changes in accounting regulations and bureaucratic red-tape.

\section{Conclusion}

Indonesia introduced many public sector financial management reforms during the past decade, including the unique basis of accounting which is cash towards accrual basis. The main purpose was to improve transparency and accountability of the governmental agencies. However, it was found that the reform initiatives have failed to achieve the objectives of the improved transparencies and accountabilities as indicated by the public auditors. Most of the governmental agencies ended up with high levels of "Qualified" and "Disclaimer" audit reports. We have investigated three Indonesian SNGs to explore the reasons why governmental agencies ended up with had difficulty adopting reform agendas leading to the "Qualified" opinions of the auditors. We found that in the case of the Indonesian public sector accounting reforms, the demand of, supply for, and the quality of the accounting information is not in a balanced state. There is pseudo demand for accounting information for decision-making but the public sector executives rarely use accounting information for decision-making purposes. There is a problem with the production of the information as there are no qualified accountants conversant with the public sector accounting standards and its application. The regulators are not careful enough in changing the rules and regulations related to the public sector accounting systems of the governmental agencies, leading to frequent changes in the laws. In addition there is no monitoring authority to monitor the financial activities and reporting of the governmental agencies in Indonesia. As a result the numbers of "Qualified" audit opinions on the audited financial reports of the Indonesian governmental agencies have increased significantly. Therefore, in order to make the Indonesian public financial management reforms, the reformers should try to synchronise the demand, supply and quality factors of the Indonesian public sector accounting infrastructure.

\section{References}

Al-Rai, Z \& Dahmash, N 1998, 'The Effects of Applying International Accounting and Auditing Standards to the Accounting Profession in Jordan', Advances in International Accounting, Supplement 1, pp. 179-193.

Bezes, P, Demazière, D, Le Bianic, T, Paradeise, C, Normand, R. Benamouzig, D, Pierru, F, \& Evetts, J 2012, 'New Public Management and Professionals in the Public Sector. What New Patterns beyond Opposition?' Sociologie du Travail, vol. 54, no. 1, pp.152. 
Broadbent, J \& Guthrie, J 1992, 'Changes in the Public Sector: A Review of Recent Alternative Accounting Research', Accounting, Auditing and Accountability Journal, vol. 5, no. 2, pp. 3-31. http://dx.doi.org/10.1108/09513579210011835

Chamisa, E 2000, 'The Relevance and Observance of the IASC Standards in Developing Countries and the Particular Case of Zimbabwe', The International Journal of Accounting, vol. 35, no. 2, pp. 267-286. http://dx.doi.org/10.1016/S00207063(00)00049-2

Chand, P 2005, 'Convergence of Accounting Standards in the South Pacific Island Nations The Case of Fiji', The Journal of Pacific Studies, vol. 28, no.2, pp. 269-290.

Cutler, T 2011, 'Performance Management in Public Services 'Before' New Public Management: The Case of NHS Acute Hospitals 1948-1962', Public Policy and Administration, vol. 26. no. 1, pp. 129-147.

Dahawy, K \& Conover, T 2007, 'Accounting Disclosure in Companies Listed on the Egyptian Stock Exchange', Middle Eastern Finance and Economics, vol. 1, no. 1, pp. 5-20.

Enthoven, A. 1973, Accounting and Economic Development Policy, North-Holland, Amsterdam.

Grossi, G \& Newberry, S 2009, 'Theme: Whole of Government Accounting - International Trends', Public Money \& Management, vol. 29, no. 4, pp. 209-218. http://dx.doi.org/10.1080/09540960903034968

Guthrie, J 1993, 'Australian Public Business Enterprises: Analysis of Changing Accounting, Auditing and Accountability Regimes’, Financial Accountability \& Management, vol. 9, no. 2, pp. 101-113.

Guthrie, J \& Humphrey, C 1996, 'Public Sector Financial Management Developments in Australia and Britain: Trends and Contradictions', Research in Governmental and Nonprofit Accounting', vol. 9, pp. 283-302. http://dx.doi.org/10.1111/j.14680408.1993.tb00102.x

Harun, H 2007, 'Obstacles to Public Sector Accounting Reform in Indonesia', Bulletin of Indonesian Studies, vol. 43, no. 3, pp. 365-75. http://dx.doi.org/10.1080/00074910701727613

Harun, H \& Robinson, P 2010, 'The Adoption of Accrual Accounting in Indonesian Public Sector', Research in Accounting in Emerging Economies, vol.10, pp. 233-250.

Hassan, N 1998, 'The Impact of Socio-economic and Political Environment on Accounting System Preferences in Developing Economies', Advances in International Accounting, Supplement 1, pp. 43-88.

Hood, C 1995, 'The "New Public Management" in the 1980s: Variations on a Theme', Accounting, Organizations and Society, vol. 20, no. 2/3, pp. 93-109. http://dx.doi.org/10.1016/0361-3682(93)E0001-W

Jacobs, K 1997, 'A Reforming Accountability: GPs and Health Reform in New Zealand', International Journal of Health Planning and Management, vol. 12, no. 3, pp. 169-85. http://dx.doi.org/10.1002/(SICI)1099-1751(199707/09)12:3<169::AIDHPM478>3.0.CO;2-\#

Jacobs, K 1998, 'Costing Health Care: A Study of the Introduction of Cost and Budget Reports into a GP Association’. Management Accounting Research, vol. 9, no.1, pp. 5570. http://dx.doi.org/10.1006/mare.1997.0066

Kholeif, A 2010, 'A New Institutional Analysis of IFRS', Research in Accounting in Emerging Economies, vol.10, pp. 29-55.

Kristiansen, S, Dwiyanto, A, Pramusinto, A \& Purranto, E 2008, 'Public Sector Reforms and Financial Transparency: Experiences from Indonesian Districts', Contemporary Southeast Asia, vol. 31, no. 1, pp. 64-87. http://dx.doi.org/10.1355/CS31-1C 
Lapsley, I 1999, 'Accounting and the New Public Management: Instruments of Substantive Efficiency or a Rationalising Modernity?', Financial Accountability \& Management, vol. 15, no. 3, pp. 201-207. http://dx.doi.org/10.1111/1468-0408.00081

Larson, R 1993, 'International Accounting Standards and Economic Growth: An Empirical Investigation of their Relationship in Africa', Research in Third World Accounting, vol. 2, pp. 27-43.

Lawrence S 1999, 'From Welfare State to the Civil Society: The Constitutive Use of Accounting in the Reform of the NZ Public Sector' Critical Perspective on Accounting, vol. 10, issue 2, pp. 223-246. http://dx.doi.org/10.1006/cpac.1998.0274

Lee, C 1987, 'Accounting Infrastructure and Economic Development', Journal of Accounting and Public Policy, vol. 6, no. 2, pp. 75-85. http://dx.doi.org/10.1016/02784254(87)90007-X

Lee, E 2012, 'The New Public Management Reform of State-funded Social Service Nonprofit Organizations and the Changing Politics of Welfare in Hong Kong', International Review of Administrative Sciences, vol. 78, No. 3, pp.537-553.

Lee, J 2001, Reporting of Infrastructure Assets: The Disclosure Practices In Australia and Their Association With Regulation And Report-Users' Interests. Unpublished PhD Thesis, University of New England, Australia.

Llewellyn, S \& Northcott, D 2005, 'The Average Hospital', Accounting, Organisations and Society, vol. 30, no. 6, pp. 555-583. http://dx.doi.org/10.1016/j.aos.2004.05.005

Lowe, A 2000, 'The construction of a network at Health Waikato: Toward Clinical Budget Project', Accounting, Auditing and Accountability Journal, vol. 13, no. 1, pp. 84-114. http://dx.doi.org/10.1108/09513570010316162

Lucio, M, Noon, M \& Jenkins, S 1997, 'Constructing the Market: Commercialization and Privatization in the Royal Mail', Public Administration, vol. 75, Summer, pp. 267-282.

Luder, K 1992, 'A Contingency Model of Governmental Accounting Innovation in the Political-Administrative Environment', Research in Governmental and Nonprofit Accounting, vol. 7, pp. 99-127.

Manning, N 2001, 'The Legacy of the New Public Management in Developing Countries', International Review of Administrative Sciences, vol. 67, no.2, pp. 297-312.

Marwata \& Alam, M 2006, 'The Interaction Amongst Reform Drivers in Governmental Accounting Changes - The Case of Indonesian Local Government', Journal of Accounting and Organizational Change, vol. 2, no. 2, pp. 144-163.

McCulloch, B 1993, 'New Zealand Leads in Government Management Reform', Government Accountants Journal, Spring, pp. 27-32.

Meier, K and O’Toole, Jr. L, 2009, 'The Proverbs of New Public Management: Lessons from an Evidence-based Research Agenda', The American Review of Public Administration, vol. 39, no. 1, pp. 4-22.

Merchant, K \& Van der Stede, W 2012, Management Control Systems, Pearson Education Limited, Essex, England.

Miles, M \& Huberman, A 1994, Qualitative Data Analysis, second edition, SAGE Publications, Thousand Oaks, California.

Ministry of Finance, n.d., 'Indonesian Public Sector Financial Management Reform Framework', Ministry of Finance, Jakarta.

Mir, M \& Rahaman, A 2003a, 'Organisational Knowledge Creation and the Commercialisation of State Mail Service', The International Journal of Public Sector Management, vol. 16, nos. 4 \& 5, pp. 373-392.

Mir, M and Rahaman, A 2003b, 'Partners in reform: A narrative analysis of the role of accounting in the reform process of a public sector agency'. Proceedings of the Interdisciplinary Perspectives on Accounting Conference, Madrid, Spain July 13-16. 
Mir, M \& Rahaman, A 2005, 'The Adoption of International Accounting Standards in Bangladesh: An Exploration of Rationale and Process', Accounting, Auditing \& Accountability Journal, vol. 18, no. 6, pp. 816-841.

Mir, M \& Rahaman, A 2006, 'Leadership, Accounting, and the Reform Process of a Public Sector Agency: A Narrative Analysis', Financial Accountability \& Management, vol. 22, no. 2, pp. 157-178.

Mir, M \& Rahaman, A 2007, 'Accounting and Public Sector Reforms: A Study of a Continuously Evolving Governmental Agency in Australia', Accounting, Auditing \& Accountability Journal, vol. 20, no. 2, pp. 237-268.

Mirghani, M 1998 'The Development of Accounting Standards in the Kingdom of Saudi Arabia: An International Accounting Standards Perspective', Advances in International Accounting, Supplement 1, pp. 195-206.

Newberry, S \& Pallot J, 2004, 'Freedom or Coercion? NPM Incentives in New Zealand Central Government Departments’, Management Accounting Research, vol. 15, no.3, pp. 247-266.

Parker, L \& Guthrie, J 1993, 'The Australian Public Sector in the 1990s: New Accountability Regimes in Motion', Journal of International Accounting, Auditing and Taxation, vol. 2, no. 1, pp. 59-81. http://dx.doi.org/10.1016/1061-9518(93)90015-L

Pallot, J 1992, 'Elements of a Theoretical Framework for Public Sector Accounting', Accounting, Auditing and Accountability Journal, vol. 5, no. 1, pp. 38-59. http://dx.doi.org/10.1108/09513579210008244

Puxty, A 1997, 'Accounting choice and a theory of crises: the case of post-privatization British Telecom and British Gas'. Accounting, Organizations and Society, vol. 22, no.7, pp. 713-735.

Saleh, Z 2007, 'Malaysian Governmental Accounting: National Context and User Orientation', International Review of Business Research Papers, vol.3, no.2, pp. 376 384.

Tomkins, C 1987, 'Achieving Economy, Efficiency and Effectiveness in the Public Sector'. The Institute of Chartered Accountants of Scotland.

Wallace, R 1990, 'Accounting in Developing Countries: A Review of the Literature', Research in Third World Accounting, vol. 1, pp. 1-22.

Wallace, R and Briston, R 1993, 'Improving the Accounting Infrastructure in Developing Countries', Research in Third World Accounting, vol. 2, pp. 201-224.

Yin, R 2003, 'Case Study Research: Design and Methods', third edition, SAGE Publications, Thousand Oaks, California. 


\section{Appendix 1: Accounting Infrastructure of a Country}

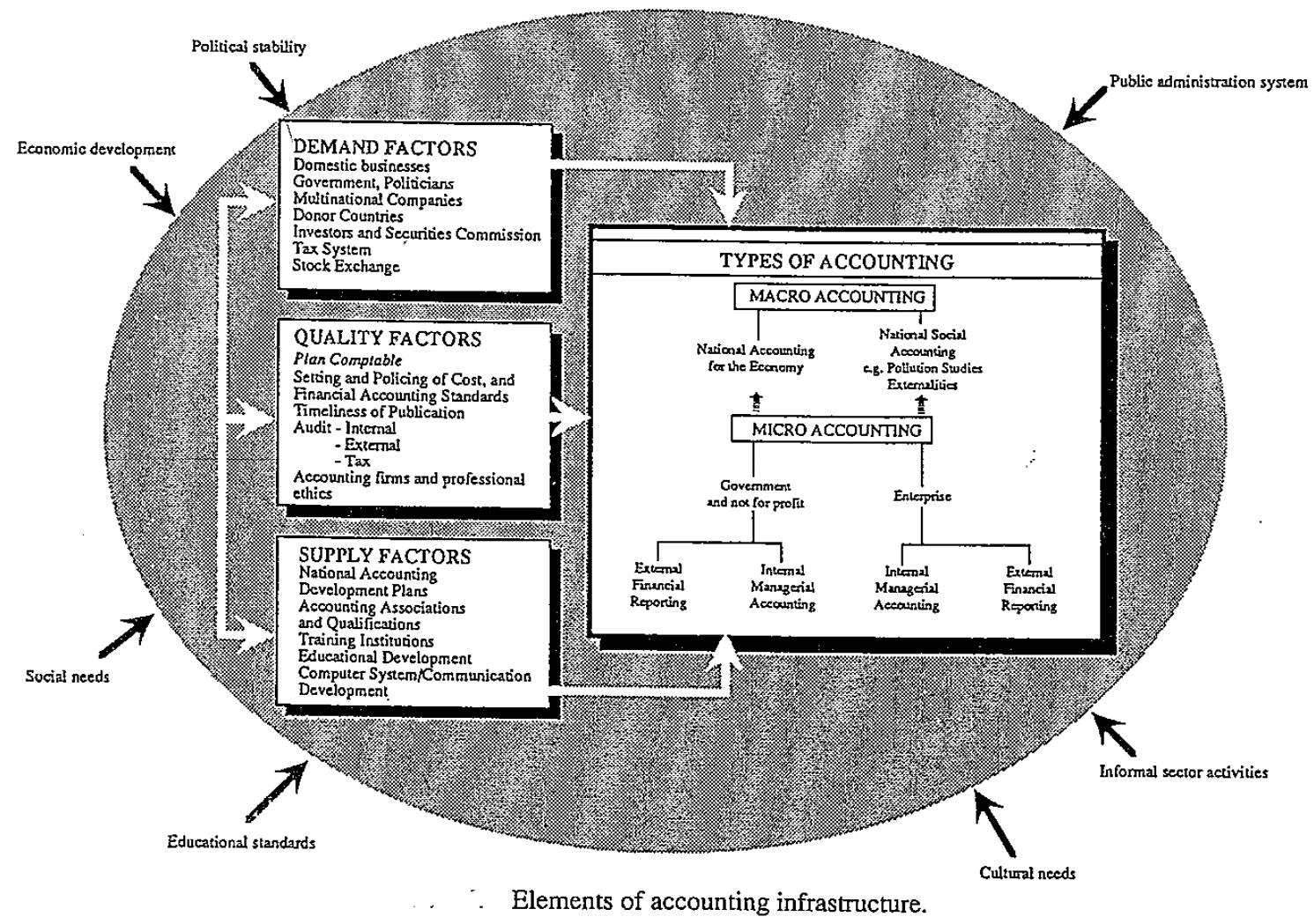

(Source: Wallace and Briston (1993, p. 202) 


\section{Appendix 2: Indonesian Public Sector Financial Management Reform Framework}

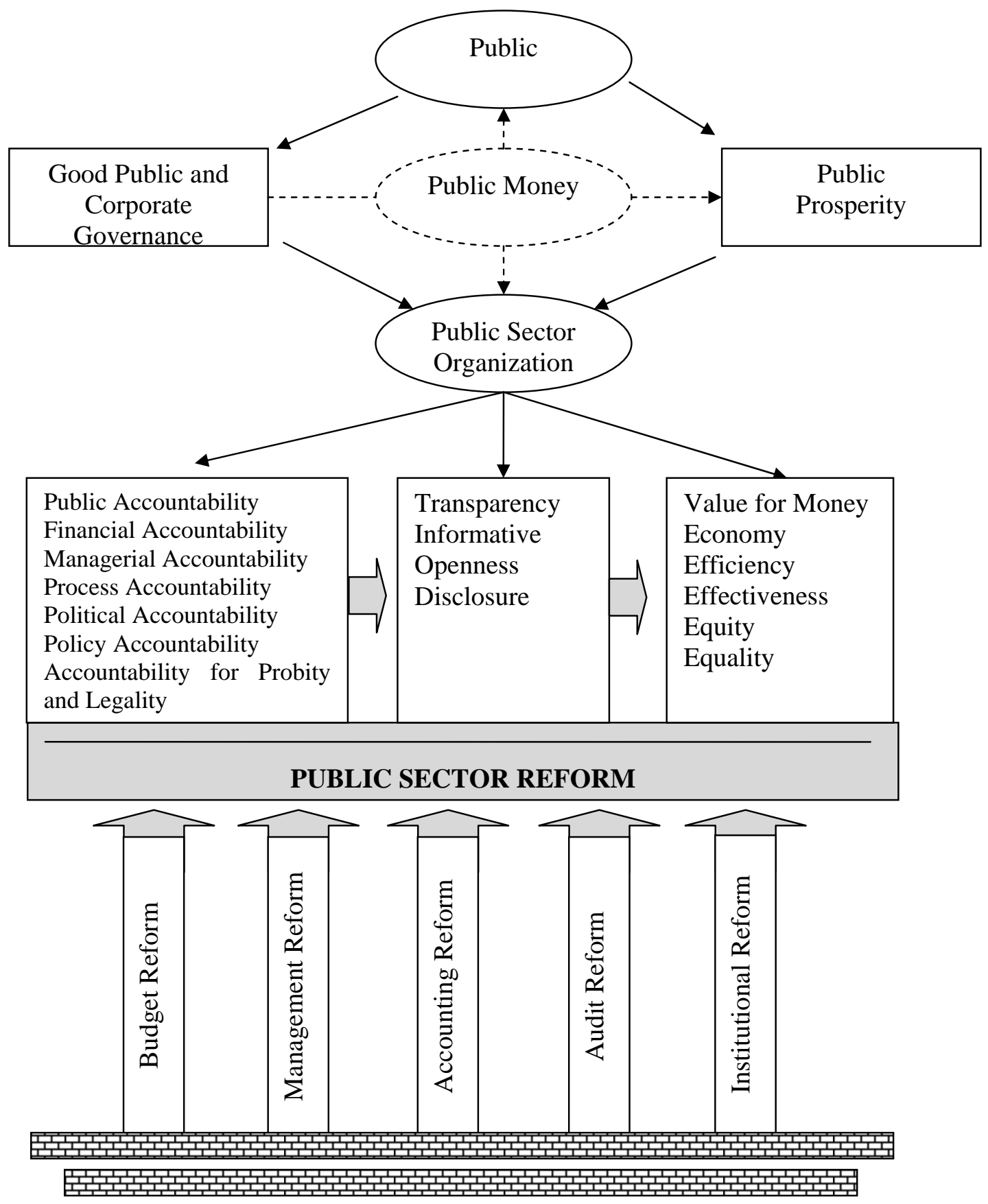

Source: Ministry of Finance, n.d. 


\section{Appendix 3: List of Interviewees}

\begin{tabular}{|c|l|}
\hline $\begin{array}{c}\text { Number of } \\
\text { Interviewees in } \\
\text { SNGs }\end{array}$ & \\
\hline Jakarta & \\
\hline J-1 & Position of Interviewees \\
\hline J-2 & Head of Financial Report Section \\
\hline J-3 & Staff, Financial Report Section \\
\hline Tangerang & \\
\hline T-1 & Secretary of Region \\
\hline T-2 & Head of Planning \& Development Regional Office \\
\hline T-3 & Head, Financial Management Office \\
\hline T-4 & Assistant of Mayor, Control Section \\
\hline T-5 & Staff, Regional Supervision \\
\hline Pandeglang & \\
\hline P-1 & Head of Section, Financial Management Office \\
\hline P-2 & Head, Financial Management Office \\
\hline P-3 & Staff, Regional Supervision \\
\hline P-4 & Head, Planning Office \\
\hline P-5 & Head of Section, Tax and Income \\
\hline P-6 & Head, Local Parliament \\
\hline P-7 & Chairman, Democratic Struggle Party \\
\hline & \\
\hline & \\
\hline & \\
\hline & \\
\hline
\end{tabular}

